\title{
The Sound of a Buk (Korean Traditional Drum) Attenuates Anaphylactic Reactions by the Activation of Estrogen Receptor- $\beta$
}

\author{
Hee-Yun Kim ${ }^{a}$ Kyung-Ja Ko ${ }^{a}$ Sun-Young Nama Hyun-Ja Jeong ${ }^{b}$ \\ Hyung-Min Kim ${ }^{a}$ \\ ${ }^{a}$ Department of Pharmacology, College of Korean Medicine, Kyung Hee University, Seoul, and \\ ${ }^{b}$ Department of Food Technology and Department of NanoBio Tronics, Hoseo University, Asan, Republic of Korea
}

\section{Key Words}

Anaphylaxis · Buk music $\cdot$ Estrogen receptor- $\beta$.

Hypoxia-inducible factor-1 $\alpha \cdot$ Vascular endothelial growth factor

\begin{abstract}
Background: Anaphylaxis is associated with systemic vasodilation that causes low blood pressure and induces hypoxic brain damage. The sound of a Buk (Korean traditional drum) is similar to the human heart beat and affects blood pressure, heart rate, and the nervous system by increasing physiological excitation and sympathetic nervous system activity. So, this study focused on the effect of Buk music as a means of treating anaphylaxis. Methods: Mice were given an intraperitoneal injection of compound 48/80 $(6.5 \mathrm{mg} / \mathrm{kg}$, a mast cell degranulator). After compound 48/80 injection, mice were exposed to Buk music and white noise for $5 \mathrm{~min}$ in a sound isolation booth. The mortality rate was checked over the next $40 \mathrm{~min}$. Levels of hypoxia-inducible factor-1a (HIF-1a) and vascular endothelial growth factor (VEGF) in the serum and brain tissues were analyzed by Western blotting, quantitative real-time PCR, and ELISA methods. Results: Exposure to Buk music significantly reduced compound
\end{abstract}

H.-Y.K. and K.-J.K. contributed equally to this work.

\section{KARGER 125}

(๑) 2015 S. Karger AG, Basel

$1018-2438 / 15 / 1674-0242 \$ 39.50 / 0$

E-Mail karger@karger.com

www.karger.com/iaa 48/80-induced mortality and histamine release, as well as HIF- $1 a$ and VEGF levels compared with the compound 48/80 group or compound $48 / 80$ and white noise group. Buk music also reduced levels of tumor necrosis factor- $a$, and significantly increased estrogen receptor- $\beta$ mRNA levels. Conclusion: These results indicate that Buk music has potential for the treatment of anaphylaxis.

(c) 2015 S. Karger AG, Basel

\section{Introduction}

Anaphylaxis is a systemic allergic reaction that is usually treated in emergency departments [1]; it is a severe immediate-type hypersensitivity reaction characterized by life-threatening upper airway obstruction, bronchospasm, and hypotension [2]. Anaphylaxis causes hypotension by inducing the release of histamine from mast cells [3-5], and severe anaphylaxis is defined when accompanied by hypoxia, hypotension, or neurologic compromise, typically manifested by collapse [6].

A recent study demonstrated that alterations in protein expression profiles after allergen sensitization and challenge resembled those observed in hypoxia [7], which

Correspondence to: Prof. Hyun-Ja Jeong

Department of Food Technology and Department of NanoBio Tronics, Hoseo University 20, Hoseo-ro, 79 beon-gil, Baebang-eup

Asan 336-795 (Republic of Korea)

E-Mail hjjeong@hoseo.edu

Co-corresponding author: Prof. Hyung-Min Kim

Department of Pharmacology, College of Korean Medicine, Kyung Hee University

26, Kyungheedae-ro, Dongdaemun-gu

Seoul 130-701 (Republic of Korea)

E-Mail hmkim@khu.ac.kr 
Fig. 1. Features of a Buk.
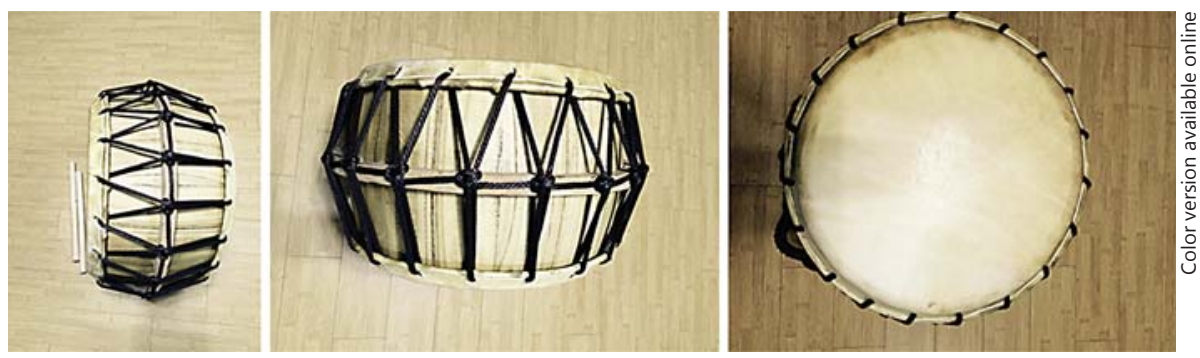

is an essential developmental and physiological stimulus that plays key roles in the pathophysiology of allergy, heart disease, cancer, neuron death, cerebrovascular disease, and chronic lung disease [8-10]. Hypoxia induces the transcription of a range of physiologically important genes, including vascular endothelial growth factor (VEGF), which is mediated by hypoxia-inducible factor-1 (HIF-1). It also produces an inflammatory response characterized by increases in reactive oxygen species, venular leukocyte-endothelial adherence and emigration, and vascular permeability [9]. Previously, we reported that the production of histamine and inflammatory cytokines is induced by evoking HIF-1 $[9,10]$.

Estrogen has potent neuroprotective effects in animal models of brain disease or injury via various mechanisms, which include anti-inflammation, reduction in oxidative stress and excitotoxicity, anti-apoptosis, and vasodilation in the ischemic brain [11], and it has also been reported that estrogen receptor- $\beta$ (ER- $\beta$ ) activation in the brain is associated with reduced blood-brain barrier (BBB) breakdown via the inhibition of HIF-1a/ VEGF signaling [12].

The Buk (fig. 1) is a Korean traditional drum with a body shaped like a barrel. Its body is normally made of wood such as poplar and paulownia, which produce a deep, hollow, clear sound. The sound of a Buk has been found to help to reduce agitation and may promote relaxation and increase parasympathetic nervous system activity. Its sound can cheer up people who are feeling down, reduce stress, and regulate blood flow, presumably because it sounds like a heartbeat. Listening to music is a complex phenomenon, involving psychological, emotional, neurological, and cardiovascular changes, as well as behavioral modifications of breathing [13]. So, we hypothesized that Buk music might regulate the hypoxia induced by anaphylaxis, which has not been studied previously, and investigated the effect of Buk music on anaphylaxis induced by compound $48 / 80$ in an animal model.

Anti-Allergic Effect of Buk Music

\section{Materials and Methods}

\section{Animals}

The original stock of male ICR (4 weeks old) was purchased from the Dae-Han Experimental Animal Center (Daejeon, Republic of Korea). Animal care and experimental procedures used were approved by the Animal Care Committee of Kyung Hee University [KHUASP (SE)-12-019].

\section{Reagents}

Avidin peroxidase, bicinchoninic acid, ketotifen, and other reagents were purchased from Sigma (St. Louis, Mo., USA). Antimouse VEGF/interleukin (IL)- $1 \beta /$ tumor necrosis factor (TNF)- $\alpha$ purified antibody, anti-mouse VEGF/IL- $1 \beta /$ TNF- $\alpha$ biotin-conjugated antibody, and recombinant mouse VEGF/IL-1 $\beta / T N F-\alpha$ were purchased from BD Biosciences Pharmingen (San Diego, Calif., USA). Antibody for HIF-1 $\alpha$ and GAPDH were obtained from Santa Cruz Biotechnology (Santa Cruz, Calif., USA).

\section{Compound 48/80-Induced Systemic Anaphylaxis}

Mice were given an intraperitoneal injection of compound $48 / 80(6.5 \mathrm{mg} / \mathrm{kg})$. The period used to observe mortality was based on the results of a pretest during which mice died within $30 \mathrm{~min}$ of administration. Ketotifen was used as a positive control $(1 \mu \mathrm{g} /$ $\mathrm{kg}$, p.o.). Mortality was monitored for $40 \mathrm{~min}$ after injection. Five mice were allocated to each group and divided into 5 groups: (1) no treatment, (2) compound 48/80 injection, (3) compound 48/80 injection and treatment with ketotifen, (4) compound 48/80 injection and exposure to Buk music, and (5) compound 48/80 injection and exposure to white noise. Three independent experiments were performed ( $n=15$ /group).

\section{Music Exposure}

Jajinmori-jangdan and Hwimori-jangdan (rhythmic cycles) of Buk music were played by K.-J.K. The playing conditions were as follows: Jajinmori-jangdan, a rhythmic cycle of 12 beats, $4+4+4$ $+4(12 / 8$ meter, $d=96-144)$, in an allegro-moderated tempo, and Hwimori-jangdan, a rhythmic cycle of 4 beats, $2+2$ (4/4 meter, $d=208-230$ ), in a presto tempo. The sound of a Buk is a match for the frequency of a baritone voice (139.9-355.2 Hz). Background sound levels in a special isolation booth were 10-40 $\mathrm{dB}$ for the compound 48/80 and ketotifen groups, and $70 \mathrm{~dB}$ for the Buk music and white noise groups. Mice were exposed to Buk music or white noise for $5 \mathrm{~min}$. All experiments were carried out in an environment free of other sounds. Buk music was recorded and copied using a MP3 player to ensure precisely the same music was played for mice in all treatment groups. 


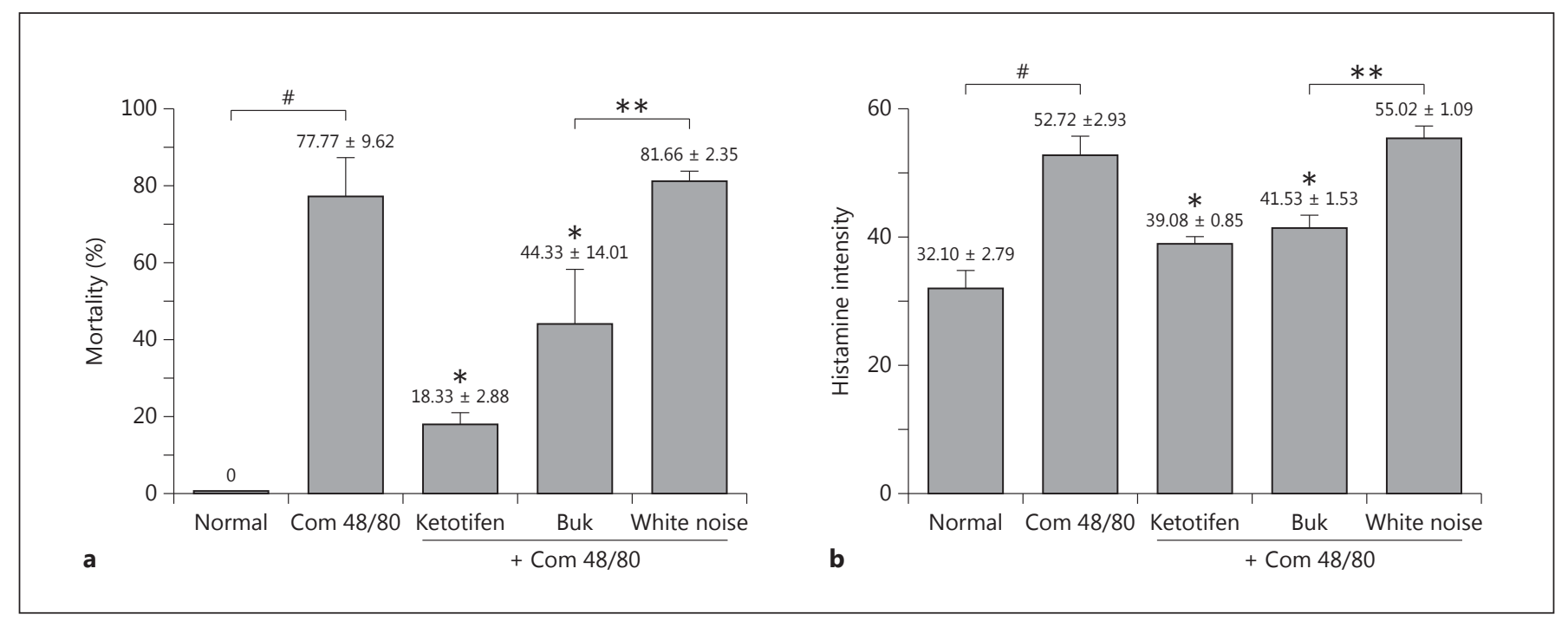

Fig. 2. Effect of Buk music on compound 48/80-induced systemic anaphylaxis. After mice had been injected with compound 48/80 $(6.5 \mathrm{mg} / \mathrm{kg})$, they were exposed to Buk music or white noise for $5 \mathrm{~min}$. Ketotifen was orally administered $(1 \mathrm{mg} / \mathrm{kg}) 1 \mathrm{~h}$ before compound $48 / 80$ injection $(6.5 \mathrm{mg} / \mathrm{kg})$. a Mortality is calculated as the

\section{Histamine Assay}

Histamine content in the serum was measured using the $o$ phthalaldehyde spectrofluorometric procedure. Fluorescent intensities were measured at $440 \mathrm{~nm}$ (excitation at $360 \mathrm{~nm}$ ) with a spectrofluorometer.

\section{Western Blot Analysis}

Western blot analysis was performed on brain tissue extracts, as previously described [8].

\section{Quantitative Real-Time PCR}

Quantitative real-time PCR was performed using SYBR Green master mix, and mRNA levels were analyzed using an ABI StepOne real-time PCR system (Applied Biosystems, Foster City, Calif., USA). Primer sequences for the reference gene GAPDH and genes of interest were as follows: GAPDH (5'-TCGACAGTCAGCCGCATCTTCTTT- ${ }^{\prime}$ and $5^{\prime}$-ACCAAATCCGTT GACTCCGACCTT-3'); HIF-1a (5'-GAAGTGGCTTTGGAGTTTCC- $3^{\prime}$ and $5^{\prime}$-CATCTCTCTGGATTTTGGCA), and VEGF (5'-ACCGCGAGGCAGCTTGAGTT- ${ }^{\prime}$ and $5^{\prime}$-ACCGCCTTGGCTTGTCACAT- $\left.3^{\prime}\right)$. Typical profile times used were as follows; initial step at $95^{\circ} \mathrm{C}$ for $10 \mathrm{~min}$ followed by a second step at $95^{\circ} \mathrm{C}$ for $15 \mathrm{~s}$ and $60^{\circ} \mathrm{C}$ for $30 \mathrm{~s}$ for 40 cycles. Levels of target mRNAs were normalized versus GAPDH. Data were analyzed using the $\Delta \Delta \mathrm{C}_{\mathrm{T}}$ method.

\section{Enzyme-Linked Immunosorbent Assay}

Cytokine levels in the serum and brain were analyzed by ELISA, as described previously [8]. Cytokine levels in the brain were divided according to the total protein levels, which were estimated using a bicinchoninic acid protein assay kit (Pierce, Rockford, Ill., USA). number of dead mice $\times 100 /$ total number of experimental mice. b Serum histamine was analyzed using a histamine assay. Values are means \pm SEM. ${ }^{*} \mathrm{p}<0.05$ vs. normal mice, ${ }^{*} \mathrm{p}<0.05$ vs. the compound $48 / 80$ alone, ${ }^{* *} \mathrm{p}<0.05$ vs. $48 / 80+$ white noise. Com $48 / 80$ = Compound 48/80; normal $=$ naïve mice.

\section{Statistical Analysis}

Data are expressed as means \pm SEM. The analysis was performed using SPSS (version 11.5). Statistical significance was accepted for values of $\mathrm{p}<0.05$. Treatment effects were analyzed using the independent $t$ test and one-way analysis of variance followed by Tukey's multiple range tests.

\section{Results}

\section{Effect of Buk Music on Anaphylaxis}

To examine the effects of Buk music on anaphylactic reactions, we used an in vivo model of systemic anaphylaxis. Compound 48/80 (6.5 mg/kg) was used as a systemic fatal anaphylaxis inducer. After injecting compound 48/80 intraperitoneally, mice listened to Buk music for $5 \mathrm{~min}$. As a result, compound 48/80 induced a fatal reaction in about $77 \%$. Exposure to Buk music significantly reduced mortality from compound 48/80 ( $\mathrm{p}<0.05$; fig. 2a). The oral administration of ketotifen also reduced mortality induced by compound $48 / 80$ ( $\mathrm{p}<0.01$; fig. $2 \mathrm{a}$ ). Anaphylaxis is induced by mast cell degranulation [4], and to clarify the effect of Buk music on mast cell degranulation, we measured serum histamine levels. Histamine levels in the compound 48/80 group were significantly higher than in the normal group ( $<<0.05$; fig. $2 b)$. However, histamine levels were significantly lower in the Buk 


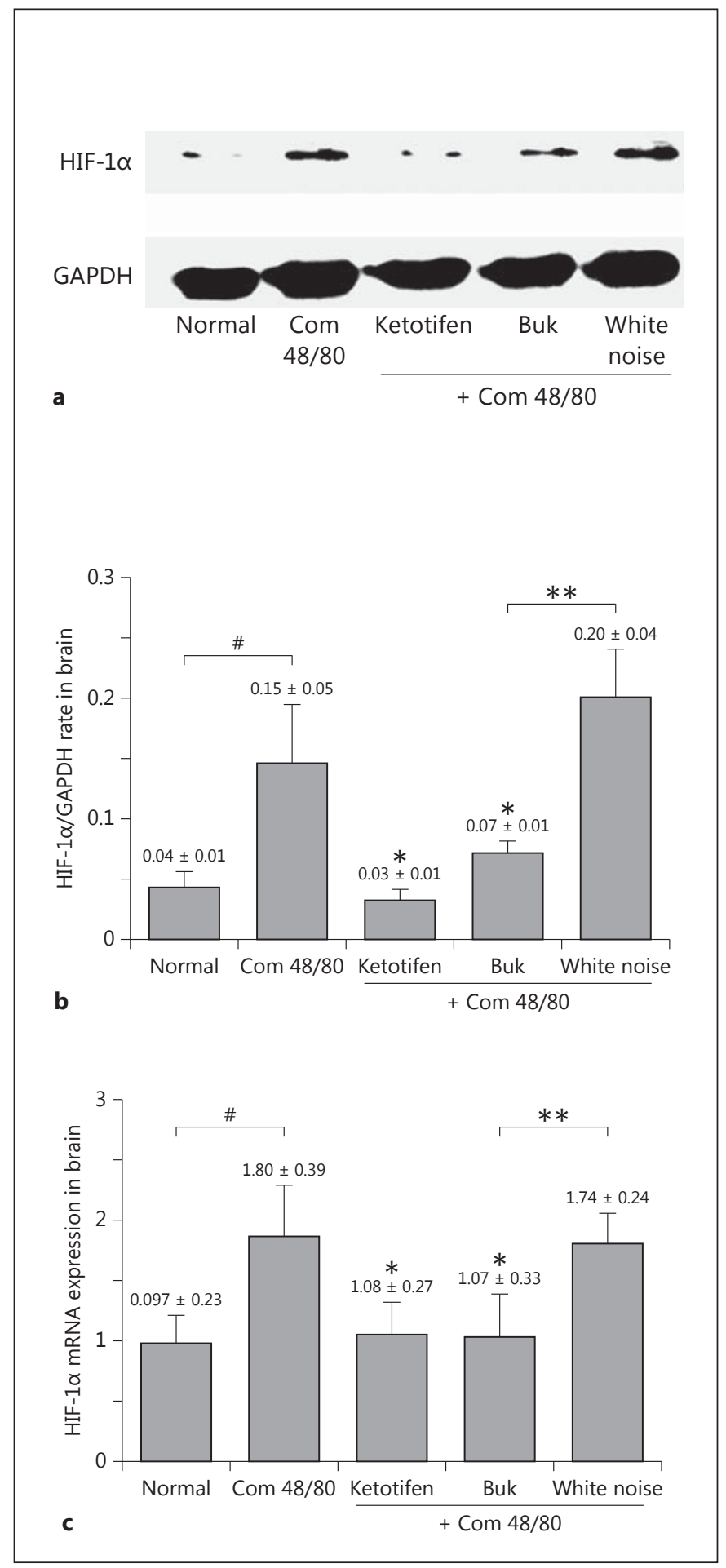

Fig. 3. Effect of Buk music on HIF-1a levels in the brain. a HIF$1 a$ protein levels in the brain were analyzed by Western blotting. b HIF-1 a protein levels were quantitated by densitometry. c HIF1 a mRNA expression was assessed by quantitative real-time PCR. Values are means \pm SEM. ${ }^{*} \mathrm{p}<0.05$ vs. normal mice, ${ }^{*} \mathrm{p}<0.05 \mathrm{vs}$. the compound $48 / 80$ alone, ${ }^{* *} \mathrm{p}<0.05$ vs. the compound $48 / 80+$ white noise. Com 48/80 = Compound 48/80; normal $=$ naïve mice.

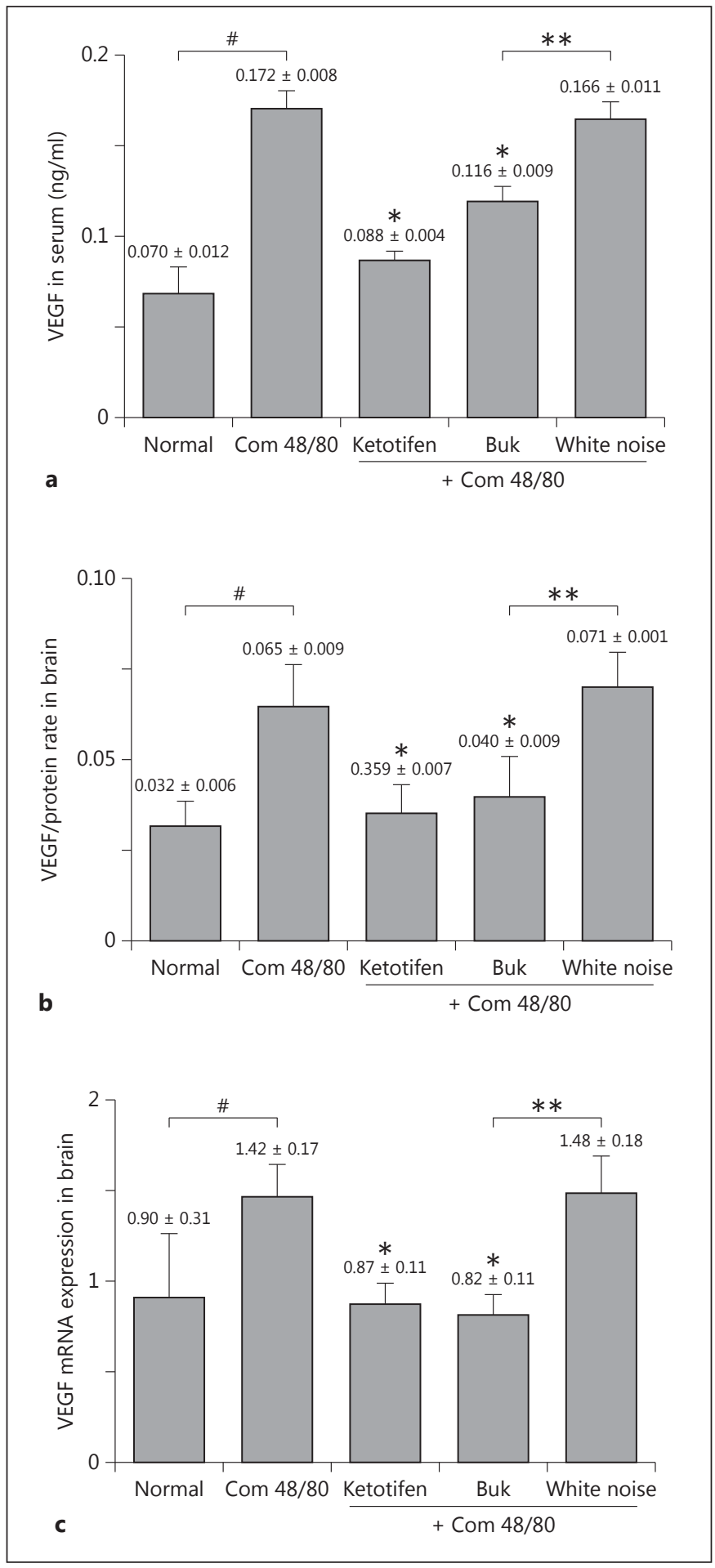

Fig. 4. Effect of Buk music on VEGF levels in the serum and brain. a, b VEGF levels in the serum and brain were analyzed by ELISA. c VEGF mRNA levels in the brain were assessed by quantitative real-time PCR. Values are means \pm SEM. ${ }^{\#} \mathrm{p}<0.05$ vs. normal mice, ${ }^{*} \mathrm{p}<0.05$ vs. the compound $48 / 80$ alone, ${ }^{* *} \mathrm{p}<0.05$ vs. the compound 48/80 + white noise. Com 48/80 = Compound 48/80; normal $=$ naïve mice. 


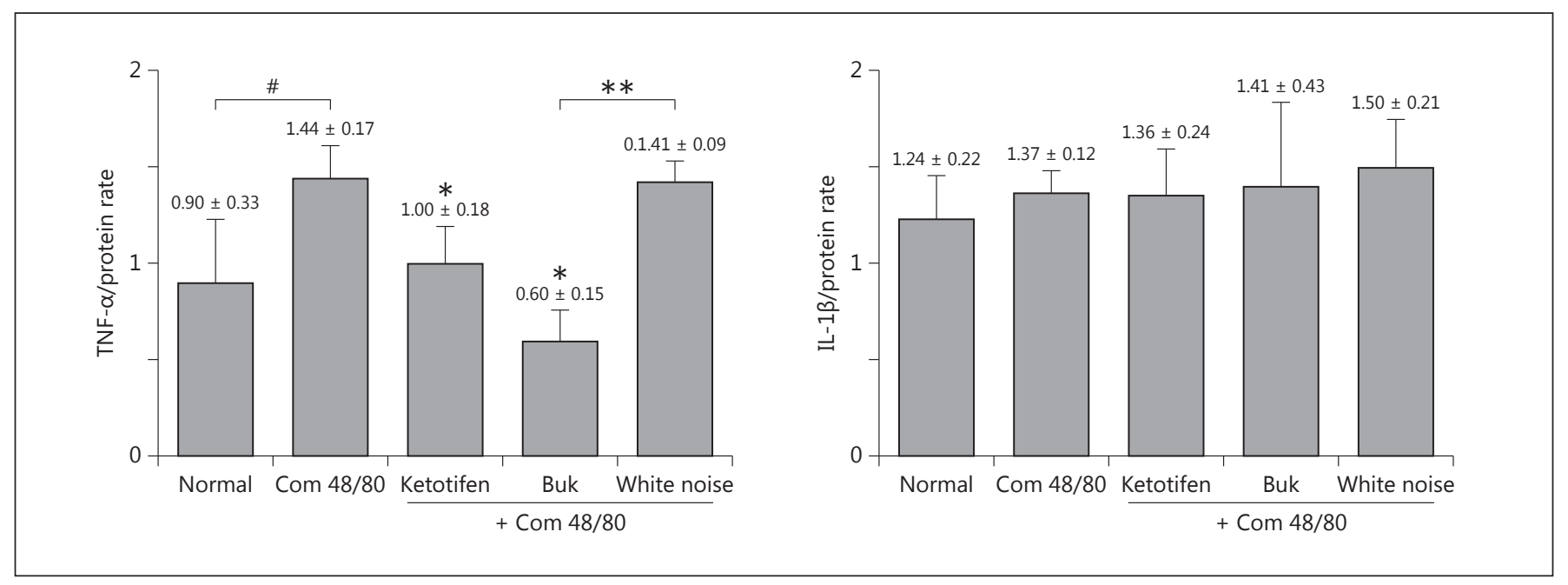

Fig. 5. Effect of Buk music on inflammatory cytokine levels in the brain. Cytokine levels were assessed by ELISA. Values are means \pm SEM. ${ }^{*} \mathrm{p}<0.05$ vs. normal mice, ${ }^{*} \mathrm{p}<0.05$ vs. the compound $48 / 80$ alone, ${ }^{* *} \mathrm{p}<0.05$ vs. the compound 48/80 + white noise. Com 48/80 = Compound 48/80; normal = naïve mice.

music group than in the compound $48 / 80$ group $(\mathrm{p}<0.05$; fig. 2b). White noise did not affect compound $48 / 80$-induced anaphylaxis (fig. 2). Buk music also significantly reduced mortality and histamine levels compared with the white noise group ( $\mathrm{p}<0.05$; fig. 2$)$.

\section{Effect of Buk Music on HIF-1 $\alpha$ Levels in the Brain}

In a previous study, it was suggested that anaphylactic shock causes brain injury by inducing cerebral hypoxia due to hypoperfusion following hypotension [14]. The hypoxia response system, which is mediated by the transcriptional activator HIF-1 $\alpha$, functions as a key regulator of oxygen homeostasis that facilitates both oxygen delivery and adaptation to oxygen deprivation [15]. Thus, Western blotting was performed to check the expression level of brain HIF-1 $\alpha$ in systemic anaphylaxis. It was found that HIF-1a levels were significantly up-regulated in compound 48/80-induced anaphylactic reactions, whereas exposure to Buk music significantly reduced expression of HIF- $1 \alpha$ proteins ( $<<0.05$; fig. $3 a, b)$. To determine whether the induction of HIF- $1 a$ mRNA by compound $48 / 80$ activated HIF-1, we performed quantitative real-time PCR. The results showed that HIF-1 $\alpha$ mRNA levels were increased in the compound 48/80 group but were significantly lower in the Buk music group ( $\mathrm{p}<0.05$; fig. 3c). Buk music also significantly reduced HIF-1a levels compared with the white noise group ( $\mathrm{p}<0.05$; fig. 3 ). Oral administration of ketotifen also significantly reduced HIF-1 $\alpha$ levels in the brain ( $p<0.05$; fig. 3 ).

\section{Effect of Buk Music on VEGF Levels in the Serum and Brain}

HIF- $1 \alpha$ is activated by ischemia and induces VEGF expression [9], and, thus, ELISA was used to check VEGF levels in the serum and brain. Compound 48/80 significantly increased VEGF levels in the serum and brain ( $<<0.05$; fig. $4 \mathrm{a}, \mathrm{b})$, but exposure to Buk music significantly reduced these levels $(\mathrm{p}<0.05$; fig. $4 \mathrm{a}, \mathrm{b})$. The brain VEGF mRNA levels were also significantly reduced by exposure to Buk music and by ketotifen ( $\mathrm{p}<$ 0.05; fig. 4c). Buk music also significantly decreased VEGF levels compared with the white noise group ( $\mathrm{p}<$ 0.05; fig. 4).

\section{Effect of Buk Music on Inflammatory Cytokine Levels in the Brain}

Numerous inflammatory cytokines, such as IL-1, IL-6, IL-8, and TNF- $\alpha$, have been implicated in the development of allergic inflammatory diseases [8]. Allergic reactions are known to be exacerbated by inflammatory cytokines, and, thus, we investigated the effects of Buk music on IL- $1 \beta$ and TNF- $\alpha$. Our results showed that TNF- $\alpha$ protein levels in the brain were increased by anaphylactic reactions but significantly reduced by exposure to Buk music or ketotifen. Buk music also significantly decreased TNF- $\alpha$ levels compared with the white noise group $(\mathrm{p}<$ 0.05; fig. 5). However, Buk music did not change IL- $1 \beta$ protein levels ( $\mathrm{p}<0.05$; fig. 5$)$. 


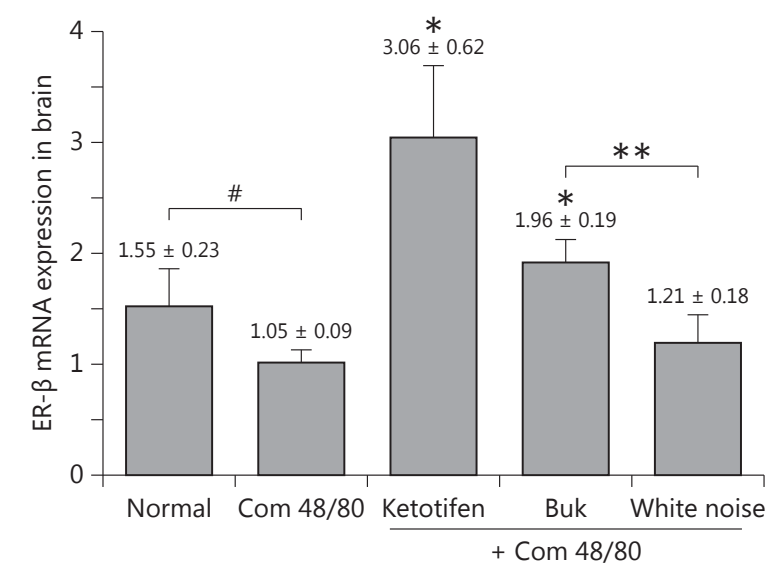

Fig. 6. Effect of Buk music on ER- $\beta$ mRNA levels in the brain. ER- $\beta$ mRNA expression was assessed by quantitative real-time PCR. Values are means \pm SEM. ${ }^{*} \mathrm{p}<0.05$ vs. normal mice, ${ }^{*} \mathrm{p}<0.05$ vs. $48 / 80$ alone, ${ }^{* *} \mathrm{p}<0.05$ vs. $48 / 80+$ white noise. Com $48 / 80=$ Compound 48/80; normal $=$ naïve mice.

\section{Effect of Buk Music on ER- $\beta$ mRNA Levels} in the Brain

A previous study showed that ER- $\beta$ activation significantly reduced the protein levels of VEGF and its transcription factor HIF-1 $\alpha$ in brain tissues and reduced BBB breakdown [12]. Thus, we examined the regulatory effects of Buk music on ER- $\beta$ mRNA levels in the brain. Compound 48/80 significantly decreased ER- $\beta$ mRNA levels compared with normal mice ( $p<0.05$; fig. 6), whereas Buk music and ketotifen significantly increased ER- $\beta$ mRNA levels in compound 48/80-administered mice ( $\mathrm{p}<0.05$; fig. 6 ). Buk music also significantly increased ER- $\beta$ mRNA levels compared with the white noise group ( $\mathrm{p}<0.05$; fig. 6 ).

\section{Discussion}

Anaphylaxis is an immediate or antibody-mediated hypersensitivity reaction and an unusual or exaggerated allergic reaction to allergens, for example to a foreign protein [16]. Anaphylaxis induces vasodilation, mucous secretion, and bronchoconstriction. In a previous study, the reason for brain injury in our mouse model was considered to be cerebral hypoxia caused by hypotension resulting from anaphylactic shock [16]. Furthermore, these responses decrease adrenergic activity and may produce altered states of consciousness and decreased neuromuscular arousal [17]. It has been shown that the entrainment of body rhythms with music increased physiological excitation and sympathetic nervous system activity [18]. Our results showed that exposure of compound 48/80-treated mice to Buk music or ketotifen significantly reduced the mortality rate and histamine, HIF- $1 \alpha$, VEGF, and TNF- $\alpha$ levels. In addition, the reduction in ER- $\beta$ mRNA expression induced by compound 48/80 was inhibited by Buk music or ketotifen. These findings indicate that exposure to Buk music inhibited compound $48 / 80$-induced allergic reactions under in vivo conditions. Our results also suggest that the anti-allergic effect of Buk music is similar to the mechanism of ketotifen. However, ketotifen is a compound with strong anti-anaphylactic and antihistaminic properties both in experimental animals and humans [19]. Ketotifen not only blocks $\mathrm{H}_{1}$ receptors and stabilizes mast cells, it also reduces intracellular calcium levels in activated mast cells $[20,21]$. In the present study, we did not note an effect of Buk music on mast cell stabilization and intracellular calcium level. Therefore, further study is necessary to clarify the detailed mechanism of Buk music on allergic reactions, although Buk music reduced compound 48/80-induced anaphylaxis.

Severe anaphylaxis is defined based on signs and symptoms of hypotension, hypoxia, and collapse [6]. Compound $48 / 80$ increases the permeability of the lipid bilayer membrane by causing a perturbation in the membrane [22] and induces histamine release from mast cells [23]. Furthermore, hypotension induced by histamine causes hypoxia in brain tissues [23], and hypoxic environments upregulate HIF-1 $\alpha$-responsive chemokines, such as VEGF, which is known to promote the recruitment and proliferation of endothelial progenitor cells, and, in addition, up-regulation of HIF-1 promotes new blood vessel development [24]. Increased vascular permeability is known to induce inflammatory responses via VEGF [25]. In our previous study, rutin exerted anti-allergic effects by suppressing VEGF expression [25]; in another study, hypoxia induced histamine synthesis and histidine decarboxylase expression via HIF-1 activation in mast cells [10]. In the present study, Buk music was found to inhibit systemic anaphylaxis and histamine release induced by compound $48 / 80$, and to reduce the increases in HIF$1 \alpha$ and VEGF levels induced by anaphylaxis. Therefore, we suggest that the anti-allergic effect of Buk music is due to the reduction in brain hypoxia.

HIF-1 is up-regulated by allergic reactions, and the expression of proinflammatory cytokines, such as IL- $1 \beta$ and TNF- $\alpha$, is increased [26]. Choi et al. [27] reported that 
hesperidin reduced the expression of TNF- $\alpha$ by suppressing HIF- $1 \alpha$ in mast cells. TNF- $\alpha$ is released from mast cells by degranulation and aggravates allergic symptoms by inducing neutrophil chemotaxis and the production of other inflammatory cytokines [28-30]. Our results show that Buk music down-regulated TNF- $\alpha$ protein levels, which suggests Buk music down-regulated TNF- $\alpha$ by inhibiting HIF-1 activation.

Estrogen has potent neuroprotective effects in animal models of brain disease or injury [11], and prevents BBB disruption induced by the direct cortical application of recombinant VEGF [31]. A number of studies have reported important roles for ER- $\beta$ in affective behaviors, cognitive functions, and neurogenesis $[12,31,32]$. ER- $\beta$ activation contributes to the down-regulation of HIF-1 $\alpha$ and VEGF in the brain [12]. Furthermore, ER signaling is also involved in the suppression of immune function [33]. Our results show that the down-regulation of ER- $\beta$ mRNA levels by compound 48/80 were inhibited by exposure to Buk music, indicating Buk music inhibited anaphylaxis by inhibiting the up-regulation of HIF-1a, VEGF, and TNF- $\alpha$ following ER- $\beta$ activation.

Anaphylaxis is a serious allergic reaction that is rapid in onset and may cause death associated with systemic vasodilation $[1,3]$ resulting in hypotension and hypoxic brain damage [14]. The rhythmic patterns of Buk music use duple-division (2) and mixed-division $(2+3$ or $3+2)$ beats, and just as poems sound musical and resonant, the sound of a Buk has its own musical flowing rhythms and sequences. Jajinmori-jangdan consists of 4 fast beats with three subdivisions in the beats. According to its tempo, the rhythmic cycle can be divided into slow and fast types.
It is used to accompany songs describing violent or agitated scenes or moods. The Hwimori-jangdan is the fastest of all music rhythmic cycles, consisting of a rapid $4 / 4$ pattern with duple subdivision of beats, and is used to accompany songs describing urgent scenes or moods [34]. The sound of a Buk is similar to the human heart beat and affects blood pressure, heart rate, and the nervous systems. In the present study, we found that Buk music reduced anaphylactic reactions in a compound 48/80-induced mouse model. We suggest that the anti-allergic effect of Buk music is due to the amelioration of compound 48/80-induced hypoxia by increasing blood pressure and heart rate. However, further studies are needed to characterize the mechanisms and effects of Buk music on blood pressure and heart rate.

In conclusion, the present study shows Buk music reduces compound 48/80-induced mortality and histamine release, and also decreases levels of TNF- $\alpha$, VEGF, and HIF- $1 \alpha$ by activating ER- $\beta$. Therefore, we suggest that Buk music be considered a possible therapy for the treatment of allergic disease.

\section{Acknowledgments}

This research was supported by the Ministry of Trade, Industry and Energy of Korea through the Education Support program for Creative and Industrial Convergence (2015).

\section{Disclosure Statement}

The authors declare that they have no conflicts of interest.

\section{References}

-1 Bohlke K, Davis RL, DeStefano F, Marcy SM, Braun MM, Thompson RS: Epidemiology of anaphylaxis among children and adolescents enrolled in a health maintenance organization. J Allergy Clin Immunol 2004;113:536-542.

$>2$ Brown SG: Anaphylaxis: clinical concepts and research priorities. Emerg Med Australas 2006;18:155-169.

-3 Chang LM, Song Y, Li XM, Sampson HA, Masilamani M: Dietary elimination of soybean components enhances allergic immune response to peanuts in BALB/c mice. Int Arch Allergy Immunol 2015;166:304-310.

$>4$ Stone SF, Cotterell C, Isbister GK, Holdgate A, Brown SG; Emergency Department Anaphylaxis Investigators: Elevated serum cytokines during human anaphylaxis: identifica- tion of potential mediators of acute allergic reactions. J Allergy Clin Immunol 2009;124: 786-792.

5 Shibamoto T, Liu W, Cui S, Zhang W, Takano $\mathrm{H}$, Kurata Y: PAF, rather than histamine, participates in mouse anaphylactic hypotension. Pharmacology 2008;82:114-120.

6 Brown SG: Clinical features and severity grading of anaphylaxis. J Allergy Clin Immunol 2004; 114:371-376.

7 Fajardo I, Svensson L, Bucht A, Pejler G: Increased levels of hypoxia-sensitive proteins in allergic airway inflammation. Am J Respir Crit Care Med 2004;170:477-484.

-8 Semenza GL: Hypoxia-inducible factor 1: oxygen homeostasis and disease pathophysiology. Trends Mol Med 2001;7:345-350.
>9 Jeong HJ, Chung HS, Lee BR, Kim SJ, Yoo SJ, Hong SH, Kim HM: Expression of proinflammatory cytokines via HIF- $1 \alpha$ and NF- $\mathrm{KB}$ activation on desferrioxamine-stimulated HMC1 cells. Biochem Biophys Res Commun 2003; 306:805-811.

$>10$ Jeong HJ, Moon PD, Kim SJ, Seo JU, Kang TH, Kim JJ, Kang IC, Um JY, Kim HM, Hong $\mathrm{SH}$ : Activation of hypoxia-inducible factor-1 regulates human histidine decarboxylase expression. Cell Mol Life Sci 2009;66:13091319.

11 Strom JO, Theodorsson A, Theodorsson E: Mechanisms of estrogens' dose-dependent neuroprotective and neurodamaging effects in experimental models of cerebral ischemia. Int J Mol Sci 2011;12:1533-1562. 
12 Shin JA, Yang SJ, Jeong SI, Park HJ, Choi YH, Park EM: Activation of estrogen receptor- $\beta$ reduces blood-brain barrier breakdown following ischemic injury. Neuroscience 2013; 235:165-173.

13 Shea SA: Behavioural and arousal-related influences on breathing in humans. Exp Physiol 1996;81:1-26.

14 Ding YJ, Song H, Liu JH, Wang GH: Brain injury due to anaphylactic shock as a result of formocresol used during root canal treatment. Int Endod J 2013;46:999-1005.

15 Semenza GL: HIF-1 and mechanisms of hypoxia sensing. Curr Opin Cell Biol 2001;13: 167-171.

16 Kim NH, Kang IC, Kim HM, Jeong HJ: Evaluation of Moon-tang on allergic reactions. Immunopharmacol Immunotoxicol 2011;33: 384-390.

17 Knight WE, Rickard NS: Relaxing music prevents stress-induced increases in subjective anxiety, systolic blood pressure, and heart rate in healthy males and females. J Music Ther 2001;38:254-272.

18 Urakawa K, Yokoyama K: Music can enhance exercise-induced sympathetic dominancy assessed by heart rate variability. Tohoku J Exp Med 2005;206:213-218.

19 Martin U, Baggiolini M: Dissociation between the anti-anaphylactic and the anti-histaminic actions of ketotifen. Naunyn Schmiedebergs Arch Pharmacol 1981;316:186-189.

20 Schoch C: Effect of ketotifen fumarate, olopatadine, and levocabastine on ocular active anaphylaxis in the guinea pig and ocular immediate hypersensitivity in the albino rat. Ocul Immunol Inflamm 2005;13:39-44.
21 Jeong HJ, Jung J, Kim MG, Kim HM: Evaluation on efficacy of modern medicine ketotifen using traditional delivery science acupuncture in allergic animal models. J Drug Del Sci Tech 2014;24:234-240.

22 Tasaka K, Mio M, Okamoto M: Intracellular calcium release induced by histamine releasers and its inhibition by some antiallergic drugs. Ann Allergy Asthma Immunol 1986; 56:464-469.

23 Shin BK, Lee EH, Kim HM: Suppression of Lhistidine decarboxylase mRNA expression by methyleugenol. Biochem Biophys Res Commun 1997;232:188-191.

24 Fei ZW, Qiu MK, Qi XQ, Dai YX, Wang SQ, Quan ZW, Liu YB, Ou JM: Oxymatrine suppresses proliferation and induces apoptosis of hemangioma cells through inhibition of HIF1a signaling. Int J Immunopathol Pharmacol 2015;28:201-208.

25 Kim HY, Nam SY, Hong SW, Kim MJ, Jeong HJ, Kim HM: Protective effects of rutin through regulation of VEGF in allergic rhinitis. Am J Rhinol Allergy 2015;29:e87-e94.

26 Jung YJ, Isaacs JS, Lee S, Trepel J, Neckers L: IL-1beta-mediated up-regulation of HIF-1a via an NFkB/COX-2 pathway identifies HIF-1 as a critical link between inflammation and oncogenesis. FASEB J 2003;7: 2115-2117.

27 Choi IY, Kim SJ, Jeong HJ, Park SH, Song YS, Lee JH, Kang TH, Park JH, Hwang GS, Lee EJ, Hong SH, Kim HM, Um JY: Hesperidin inhibits expression of hypoxia inducible factor-1 alpha and inflammatory cytokine production from mast cells. Mol Cell Biochem 2007;305:153-161.
28 Walsh LJ, Trinchieri G, Waldorf HA, Whitaker D, Murphy GF: Human dermal mast cells contain and release tumor necrosis factor alpha, which induces endothelial leukocyte adhesion molecule 1. Proc Natl Acad Sci USA 1991;88:4220-4224.

29 Oh HA, Ryu JG, Cha WS, Kim HM, Jeong HJ: Therapeutic effects of traditional Korean medicine, Jeechool-Whan in allergic rhinitis model. Tang 2011;2:e9.

30 Kashiwakura J, Yanagisawa M, Lee H, Okamura Y, Sasaki-Sakamoto T, Saito S, Tokuhashi Y, Ra C, Okayama Y: Interleukin-33 synergistically enhances immune complexinduced tumor necrosis factor alpha and interleukin- 8 production in cultured human synovium-derived mast cells. Int Arch Allergy Immunol 2013;161(suppl 2):32-36.

31 Chi OZ, Barsoum S, Wen Y, Liu X, Weiss HR: $17 \beta$-estradiol prevents blood-brain barrier disruption induced by VEGF. Horm Metab Res 2004;36:272-276.

32 Handa RJ, Ogawa S, Wang JM, Herbison AE: Roles for estrogen receptor beta in adult brain function. J Neuroendocrinol 2012;24:160173.

33 Cho JL, Allanson M, Domanski D, Arun SJ, Reeve VE: Estrogen receptor- $\beta$ signaling protects epidermal cytokine expression and immune function from UVB-induced impairment in mice. Photochem Photobiol Sci 2008; 7:120-125.

34 Song BS: Korean Music Historical and Other Aspects, ed 1. Paju, Jimoondang International, 2000 . 


\section{Erratum}

In the article by Kim et al., entitled 'The sound of a Buk (Korean traditional drum) attenuates anaphylactic reactions by the activation of estrogen receptor- $\beta$ ' [Int Arch Allergy Immunol 2015;167:242-249, DOI: 10.1159/000439567], there is an error in Materials and Methods. The sample size of animals was larger than 15, therefore the third paragraph should read:

\section{Compound 48/80-Induced Systemic Anaphylaxis}

Mice were given an intraperitoneal injection of compound 48/80 (6.5 mg/kg). The period used to observe mortality was based on the results of a pretest during which mice died within $30 \mathrm{~min}$ of administration. Ketotifen was used as a positive control ( $1 \mu \mathrm{g} / \mathrm{kg}$, p.o.). Mortality was monitored for $40 \mathrm{~min}$ after injection. Mice were allocated to each group and divided into 5 groups: (1) no treatment, (2) compound 48/80 injection, (3) compound $48 / 80$ injection and treatment with ketotifen, (4) compound 48/80 injection and exposure to Buk music, and (5) compound 48/80 injection and exposure to white noise. Three independent experiments were performed. 